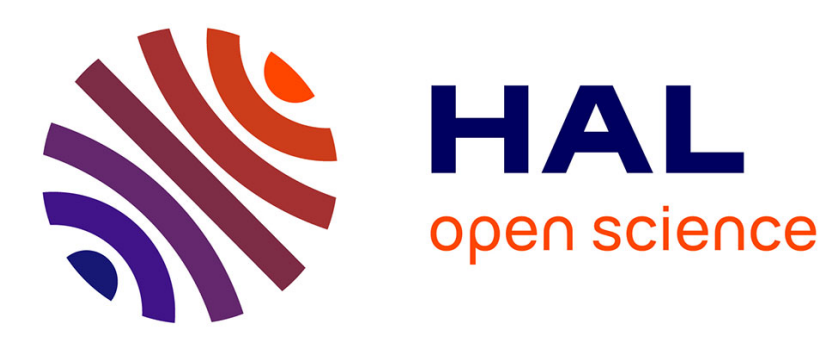

\title{
Power-seeking crime? The professional thief versus the professional launderer
}

Antoinette Verhage, Paul Ponsaers

\section{To cite this version:}

Antoinette Verhage, Paul Ponsaers. Power-seeking crime? The professional thief versus the professional launderer. Crime, Law and Social Change, 2008, 51 (3-4), pp.399-412. 10.1007/s10611-0089167-8 . hal-00478403

\section{HAL Id: hal-00478403 \\ https://hal.science/hal-00478403}

Submitted on 30 Apr 2010

HAL is a multi-disciplinary open access archive for the deposit and dissemination of scientific research documents, whether they are published or not. The documents may come from teaching and research institutions in France or abroad, or from public or private research centers.
L'archive ouverte pluridisciplinaire HAL, est destinée au dépôt et à la diffusion de documents scientifiques de niveau recherche, publiés ou non, émanant des établissements d'enseignement et de recherche français ou étrangers, des laboratoires publics ou privés. 


\title{
Power-seeking crime? The professional thief versus the professional launderer
}

\author{
Antoinette Verhage • Paul Ponsaers
}

Published online: 7 November 2008

(C) Springer Science + Business Media B.V. 2008

\begin{abstract}
Relating the concept of power to motives and objectives for criminal activities results in different images of criminals and their motivations. In this article, we aim to reflect on two different forms of crime (burglary versus money laundering) starting from a power perspective. We describe how the pursuit of power may or may not be related to crime, perpetrators and the policies that have been developed to prevent or repress these types of crime. By examining the motives behind both burglary and money laundering, we try to make clear how the concept of power and power pursuit leads to different rationales in criminal conduct. We try to determine to what extent 'rational choice' plays a role in this respect. As a conclusion, we argue that 'power' as such influences patterns of crime, victimisation and societal reactions (by means of criminal policy). The extent to which power accumulation is an outcome of crime, will in part determine the social reaction to crime and as a result, the perceived threat of crime.
\end{abstract}

In a recent article, Ruggiero ([20]:165) describes the concept of 'power crime' as crime committed by states, companies, financial institutions and other powerful organisations. "Perpetrators of power crime are offenders who possess an exorbitantly exceeding amount of material and symbolic resources when compared to those possessed by their victims. Power crime should be located against the background of differentiated opportunities which are offered to social groups. Social inequalities determine varied degrees of freedom whereby individuals are granted a specific number of choices and a specific range of potential actions they can carry out. (..)The greater the degree of freedom enjoyed, the wider the range of choices available".

A. Verhage $(\square) \cdot$ P. Ponsaers $(\bowtie)$

Research Group Social Analysis of Security (SVA), Ghent University, Ghent, Flanders, Belgium e-mail: Antoinette.Verhage@UGent.be

e-mail: Paul.Ponsaers@UGent.be 
In this contribution, we intend to apply this concept of power to two specific forms of crime and the social reaction to these crimes. With this objective, money laundering - as economic crime - and burglary - as property crime - and their relation to power and power acquisition will be discussed. These crimes are dissimilar in several respects: motives, perpetrators, risks, victimisation and approach. The aim of studying these dissimilarities is to assess to what extent motives, desires and reasons differ when applied to different forms of crime and the concept of power. In other words, our aim is to map the motives for both forms of crime in order to reflect on the extent to which committing crime is a means of striving for (more) power and gaining influence. Associated with this reflection is the choice that policy makers have made in relation to the approach to these different types of crime. How does the choice by policy makers relate to the 'power' motive in the crime considered? We reflect on these questions starting from the premise that crimes generating economic power will be approached differently on the (inter)national policy level than crimes that can be considered as part of a 'survival economy'.

\section{Power?}

First, we need to define what 'power' actually means in this regard.

Power can be exercised in several ways. Weber defined power as "the probability that one actor within a social relationship will be in a position to carry out his own will despite resistance, regardless of the basis on which this probability rests" [8]. In short, the ability to make use of power will lead to an increase in the probability that an individual will be in a position to exert his own will, without taking into account the choices of others. This means that power can only exist within relationships, in interactions with others over whom power is exerted. Without these relationships or interactions, power is insignificant. In other words, it concerns the ability of a person to control or influence the choices of other persons. From this point of view, power is a central notion in the specific description of social relations.

Sometimes social relations can be understood in terms of dominance and subordination, and this is when the notion of power becomes significant. Even Robinson Crusoe needed Man Friday Offterdinger to dominate his island. Not all relationships, however, entail the exercise of power. Relatively (un-)equal relationships may be based on constraint. We speak of power when differences among actors are substantial and blatant, obvious and unilateral. Otherwise, all relationships could be understood in terms of power, and its meaning would be lost.

Moreover, power is a relative, dynamic notion. From a structuralist point of view, the actor who achieves a certain amount of power will strive for more. The notion of power refers, in other words, to a personal ongoing inclination towards growing dominance. Rational choice theory is increasingly used in criminology and other disciplines to analyse power relationships [7]. According to this theory, individuals can be seen as actors who select particular options from within a set of choices in order to try and achieve more power. This entails that power is, for certain people, an entity that organises their choices, whilst for others it remains an irrelevant entity Some make 'rational' (read: power) choices, others do not. 
Power can take several shapes. Wright Mills [30] described the power elite as a small group of people who possess a disproportionate amount of wealth, privilege, and decision-making capacity. He focused on the relationship between the political, military and economic elite, noting that people constituting such elite share common world views. The use of power does not involve by necessity coercion or violence (force); it can also involve influence. Power can be considered as legitimate, mostly denoted by the notion of authority (political power), but it can also be regarded as evil, unjust or even illegal, and thus illegitimate. In this contribution, we are interested in forms of economic power, with a special criminological focus on the borderline between legal and illegal power.

As previously mentioned, a specific characteristic inherent to power is the fact that its expansion only takes place at the expense of others. This is also the case with economic power. A powerful actor can take options away from another's choice set, can change the relative costs of actions, can change the likelihood that a given action will lead to a given outcome, etc.

Money laundering as well as burglary can both lead to a rise in economic power, but in different fashions. The money launderer can gain economic power by taking up a position in the legal market, based on illegitimately-acquired finances. Money laundering will result in an increase in power in the legal sphere, while burglary in itself may only result in a higher income in the illegal sphere. This difference between the exercise of power in parallel but inherently distinct spheres is crucial in our reflection.

\section{Motives}

\section{Money laundering}

Is money laundering power crime? We suggest it is: money laundering, or the "process in which assets obtained or generated by criminal activity are moved or concealed to obscure their link with the crime" [10], is inherently linked to the gaining of economic power. Money laundering takes place on the threshold between the illegal and the legal economy. There are two dimensions of power related to this crime. To begin with, in order to speak of money laundering, the money needs to be 'earned' in the illegal economy by means of criminal acts, which often implies the use of violence or pressure in an illegal sense by which power is acquired. This power is subsequently transformed into 'legal' power by converting the money from illegal into seemingly legal revenues. By lifting the money over the border between the illegal and the legal, a new type of power is created: the ability to make (lawful) use of the acquired money in the world of legal corporations, investments and opportunities. This implies a rise in possibilities and as a result more potential to gain influence in the legal world. As long as criminal entrepreneurs are operating solely in the underground economy, their ability to operate on the legal market is hampered by the illegal source of their revenues. However, the moment they are able to launder these illegal revenues (thereby transforming illegal into legal funds), they will be able to utilise these funds in the legal economy, which implies the 
accumulation of economic power in two senses. Not only will this result in a growth in economic influence, but also in a strengthened position on the legal market. The legal market also allows for the use of legal mechanisms, available in that market. While operating in the underground economy, these mechanisms remain beyond the reach of criminal entrepreneurs, who will have to resort to other strategies, procedures and instruments, for example, illegal violence. After having successfully entered the legal economy, the state apparatus provides the means to exert and accumulate power in a legitimate way.

\section{Burglary}

Burglary, on the other hand, is a crime aimed at making money in a survival economy; burglars state that the reasons why they steal vary from either 'to survive, to live, to live a more luxury life', or to 'pay for my addiction'. Young burglars also remark that they get a kick out of a burglary, that a successful burglary results in a rush of adrenaline. The power motive is not present in the discourse of burglars: burglary is a 'job', something you do for a living [28]. The ability to enhance legitimate power through burglary is quasi absent, as these perpetrators predominantly remain in the illegal sphere. The ultimate dream of the burglar seems to be to succeed in a kind of treasure-hunt, in the 'jackpot', the unattended tremendous 'score'. But... every burglar knows that this happens extremely rarely, or perhaps never. There is no calculus, no power-plan, in the long-run of a career as a burglar.

\section{Profits}

The profits in money laundering

The question is to what extent gaining power in the economic sphere is actually a specific goal of money laundering? We turn to the literature for some answers. The US Department of State identified the power-motive of money laundering in the following terms: "Money laundering is now being viewed as a central dilemma in dealing with all forms of international organized crime because financial gain means power" [23]. This rationalisation was one of the motivations to start the battle against money laundering in the 80's: the fear of policy makers about a growing criminal power group in the legal economy, with far-reaching influence on formal corporations and politics. In other words, what was feared was the criminalisation of the legal economic activities [17]. Although there is much debate about the reality of these fears, Naylor states that they have never been proven to be true or realistic.

According to Masciandaro, the economic function of money laundering can be found in the transformation of potential to effective purchasing power [16]. As the revenues of underlying criminal activities cannot be employed directly in the legal sphere for consumption, investments or savings, the origins of these revenues need to be disguised. It is precisely this transformation into effective purchasing power that leads to an augmentation of lawful economic power. This does not imply that all proceeds of crime are laundered; on the contrary, only a part of criminally earned money will be laundered for use in the legal economy, namely those parts of the 
proceeds of crime that perpetrators wish to invest or save [14]. In several cases, much of the criminal revenues will be spent "on the fast life, on cars, boats and home improvements, or kept in cash form or jewellery and other 'movables' which can readily be transported overseas and is not bulky" [14]. The analysis of several court cases on money laundering and civil forfeiture proceedings reveals that, along with the opening of foreign bank accounts and the purchase of art works and antiques, expensive lifestyles are the major ways of disposing of criminal proceeds. Defendants allegedly spend their money on fur coats, hotel bills, holidays or expensive clothing [11]. These cases show that criminal entrepreneurs are not only driven by an irrational impetus to achieve power, but also by the desire to display that power in the form of status. The will to stand out and the desire to show strength are part of the incentive.

This implies that the money that actually will be laundered is money that is required to be used in a formal way, such as "savings from crime, transfers of payment for criminal purchases, and deposits of savings from crime committed overseas" [14]. Persons who engage in money laundering do this to avoid punishment and to be able to benefit from their profits through investments and consumptions in the legal economy $[21 ; 15]$. Naylor agrees on this point, adding that the reasons behind money laundering may either be the pursuit of security on a longer term basis (including the wish to leave wealth to one's heirs), or the will to apply criminal methods to legal businesses in order to make even more profit [17]. The latter is an 'emergency scenario' [17], as this would imply increasing power through legal instruments, but knowledge of how this scenario is realistic is limited due to lack of empirical evidence. Several authors warn of the stimulating effect that money laundering may have on crime: the rise in economic power makes crime more worthwhile [24], or in other words, it makes sure that crime does pay. The legal status of financial means also makes it possible for launderers to act as investors and buyers on the formal market, which may enhance criminal activities.

Suendorf, who studied several cases of money laundering, states that the profit motive is not the only reason for entrance into the legal economy. Illegal operations and the development of professional forms of money laundering are made possible thanks to the availability of legal corporations, some of which can also guarantee high living standards to launderers or even spurious forms of retirement funds. Rarely do such investments completely lack illegal objectives, or simply aim for integration into the legal sphere [22]. In other words, money laundering is not only an expression of a never-ending desire for power and influence, but is also a means to feel 'safe' or comfortable. To summarise: by laundering criminal proceeds, launderers secure their illegal businesses on the one hand, and their personal future on the other. Money laundering acts, therefore, as an insurance policy.

The profits in burglary

After a burglary, the goods taken will be sold as soon as possible. The revenues of stolen goods will be used in a variety of ways linked to the motives of the burglar: purchasing drugs, buying food and drinks, or spending the profits on cars, mobile phones, expensive clothes. Some burglars state that they hide the money in order to build up a reserve for the future [28]. Here, we see something familiar: criminal 
funds provide a form of insurance. However, the intertwining with the legal world of businesses and corporations is completely absent in the use of the profits from burglary. Burglars do not aim for a place in the legal economy nor do they want to build an 'empire' by perpetuating their crime. On the contrary, they hope to consolidate their place in illegality: it is exactly this illegal sphere that allows for the continuation of their activities.

\section{Costs}

Alongside the advantages of money laundering, there are also some negative aspects: the laundering in itself is a costly method - the cost of money laundering is estimated at around $50 \%$ of the amount of money that is to be laundered [24]. Operations may take time, as sometimes complex procedures are put in place and, at each stage of the money laundering process, there is a risk of detection. Furthermore, as soon as the money is successfully laundered, taxes need to be paid. Taking these side-effects into account, van Duyne concludes that money laundering is only applied when needed' [25]. His observation is based on the fact that laundering, on the one hand, requires certain skills which are not always available, and on the other hand, it is both risky and costly. Therefore, people will only choose to launder their proceeds when all other options are unavailable. Taking all these negative aspects into consideration, why would people choose to launder their illegal proceeds? At which point is money laundering 'needed'?

When focusing on the aspect of economic power, generated by money laundering, and not on the specific financial function of money laundering itself (i.e. the need for formal revenues), we may hypothesise that money laundering is not only carried out because it is 'needed' but also because it generates legitimate power and influence. We would argue that there is not only a need to launder money, but there is also a will. We shall now provide some examples to illustrate our point. The differentiation between the quest for economic power and the need for formal financial means may be linked to the specific crime committed, prior to the money laundering phase. From the perspective of a drug dealing business, money laundering may not specifically be 'needed' for the continuation of the business. Drug dealers, historically seen as the main agents of money laundering, may not always have an advantage in laundering their revenues. In considering that drug-related crimes are not the only crimes leading to money laundering, we will now look at other illegal activities. Looking at other types of crime that lead to the laundering of money may help us find some insights on additional motives for the use of money laundering as a tool in itself.

Analysing the data from the Belgian FIU annual report ${ }^{1}$ we see that drug crimes only represented $12 \%$ of the cases reported to the public prosecutor's office in 2007. Swindling and illegal trade in goods represented respectively 15 and $14 \%$. Moreover, serious and organised fiscal fraud (mainly VAT carrousel-fraud), crimes

\footnotetext{
${ }^{1}$ Taking into account the fact that these are cases that are actually reported to the FIU, which implies that this represents a specific group of money launderers - the ones that are caught laundering.
} 


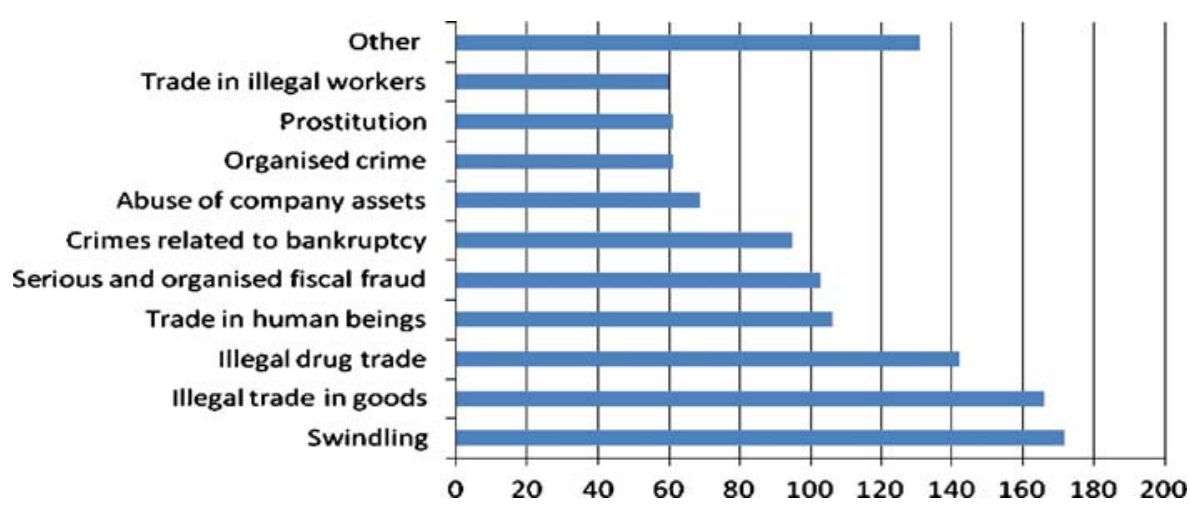

Fig. 1 Predicate crimes for money laundering. CTIF-CFI Annual Report 2007 [1]

related to bankruptcy and abuse of company assets, taken together represented almost $23 \%$ of all offences reported to the public prosecution (Fig. 1).

This difference in crime rates may be due to the expertise that is needed for money laundering. Several criminals (such as drug traffickers or human traffickers) have to rely on financial experts to get their money laundered, while professional fraudsters are self-sufficient and skilled enough to perform their own money laundering activities [18]. Another explanation may be that the latter probably have legitimate financial instruments at their disposal, unlike drug dealers who mainly work in a cash-economy. We may assume that the costs of laundering money will therefore be higher for those lacking expertise and professional instruments.

This may shed some light on the viability or otherwise of money laundering. The need or the will to launder money may become more imperative when revenues originate from specific forms of crime, committed by specific perpetrators endowed with specific skills. Hypothetically, this would suggest that money laundering occurs when all other possibilities for increasing power in the illegal economy are exhausted-which implies that in order to expand power, activities need to be shifted into the legal sphere. The search for growth potential and the drive for more power are more than just a survival strategy, which is the strategy we see in the burglar's motives.

In burglary, this cost-calculation is of minor importance, as the motives for burglary are inherently different. While money laundering is a means to increase potential for further power acquisition (an investment for the future), burglary in general does not result in more possibilities for future criminal activities. Selling the stolen goods deriving from a burglary is an investment in personal needs, not in future positions or chances. Here the power motive emerges.

\section{Power as a motive?}

Some specific types of crime that precede money laundering may well be inherently linked to the pursuit of power and influence in the legal economy. After all, criminals can also choose to remain in the illegal economy, thus avoiding the risks and costs incurred when entering the formal economy. The quest for economic 
power and influence in the formal sphere may be more typical of crimes such as fiscal fraud or swindling than of drug-related crimes or prostitution. The ability to make use of both the legal and illegal economy, combined with the intertwining of legal and illegal activities, provides the 'business criminal' with benefits transcending the mere benefits generated by illegal actions.

Dutch empirical research has shown that organised criminals are not as interested in the domination of the economic and political arena as has long been assumed. "Most criminals are not interested in generating economic and political power in the Netherlands. They fancy a certain life style and are somewhat 'addicted' to the luxury that comes with it. They like to live on the edge, but they are not particularly interested in becoming a relevant economic or political factor" [18]. The Dutch 'organised crime monitor' points out that organised crime perpetrators make use of existing flows of goods and money, but do not control or aim to control infrastructures, for example, in the transport or financial sectors. They do, however, use these sectors to commit crimes and to invest dirty money [12]. However, there are controversial views on this point: some authors explicitly warn about the infiltration of organised crime in the legal economic or political spheres [29]. As the researchers of the organised crime monitor observe, this situation is different in countries as the US or Italy, where such infiltration has been documented [12].

Van Duyne states, in this respect, that it is not organised crime as such, but 'organised business criminals' that are most successful in investing their crime money in the upper world economy [26]. They are able to invest their illegally earned money in their own enterprises, which results in an increased potential for gaining economic power and influence. This observation leads us to the assumption that gaining power in the illegal economy and transforming this power to enhance one's economic position in the legal economy (by making use of money laundering) could be a feature of a specific category of crime and criminals.

Money laundering is a crime which is inherently linked to a previously committed criminal act. Money laundering in itself is considered to be a variant of receiving stolen goods. Burglary, on the other hand, can be one of the crimes that lead to the handling or receiving of stolen goods. However, as is the case in money laundering, the launderer himself is often engaged in the predicate crime and is trying to conceal the origins of his revenues.

This is not the case for the handling of stolen goods resulting from burglary. The burglar may choose to have his earnings sold by a third party, which implies there is no extra profit for the burglar in the selling of his illegally earned goods. Burglars actually state that, although selling stolen goods is not very difficult, they are aware of the fact that the prices they get as providers of stolen goods are much lower than the prices for which the goods are resold on the market. They state that they are powerless to influence these practices, as they cannot control the market of stolen goods, as only the dealers can [28]. Furthermore, it has to be observed that the stolen goods can only be sold on the illegal market.

In the case of money laundering, however, the launderer maximises the returns of his illegally yielded income by controlling the revenues from the origins - in the illegal economy - until the final stage, when the funds have been inserted into the legal economy. 


\section{The business criminal and money laundering}

Adopting the concept of power crime, we established earlier that money laundering is a crime that produces power. Laundering illegal proceeds of criminal activities allows for integration in the formal economy, which leads to an increase in economic power, but also to a feeling of comfort and security through the disguising of the criminal origins of wealth. By laundering illegal funds, criminal entrepreneurs become real players in the formal economy, which enhances their opportunities for cooperation and partnership in the world of legitimate business. In the specialist literature we find little information on the consequences of money laundering in relation to the power position of criminal groups [18]. Some examples, however, are found of legitimate groups that try to strengthen their position through money laundering. In these cases, we actually speak of organisational crime rather than of organised crime.

Take, for example, the Lernout \& Hauspie $(\mathrm{L} \& \mathrm{H})$ case that received a great deal of attention in the Belgian press during the past year. L\&H is a Belgian company, providing speech-processing technology services. L\&H developed their market position and, by December 1999 their annual turnover added up to 212 million dollars; they employed almost 2,000 people and were represented in 40 different countries [2]. The company was applauded and praised for its entrepreneurship until, in September 2001, the Wall Street Journal published an article in which it was announced that the SEC (Securities Exchange Commission) had launched an investigation against it. This announcement resulted in a massive sale of L\&H stocks and finally marked the decline of the company, which was accused of fraudulent bookkeeping and false sales figures. After the first media impact in 2000, the year in which L\&H was dismantled, the second flow of media attention came when the court hearings for this case started in 2007 and official claims were made against L\&H for swindling, fraudulent accounting, market manipulation, and abuse of company assets, but also for money laundering [3]. L\&H allegedly used front men and front companies in order to be able to manipulate their accounts and to cover their losses. Falsified accounts generated high stock prices, and after the discovery of the fraudulent manipulations, huge debts were uncovered [27], which ultimately victimised a large number of parties. As the trial started, hundreds of people brought civil actions against L\&H [4], including Dexia Bank and KPMG [5] who are on trial themselves. Dexia even started a website, claiming their innocence in the L\&H case (http://www.dexia.be/lhsp). This type of crime symbolises the use of money laundering methods within formal economic spheres, methods which are not aimed at accessing the legal economy, nor at the 'washing' of illegally earned money, but mainly at the maintenance and expansion of economic power within the formal economy itself. L\&H used front companies to keep up the appearance of a highly successful company, thus making their revenues seem higher than they were in reality. These front companies made artificial profits that were registered as real ones, but were also used as a framework to launder company assets [27].

Another example is the famous BCCI-case (Bank of Credit and Commerce International) that caused an uproar in the 80 s. In this case, the bank was actively involved in money laundering schemes. The BCCI admitted facilitating (among 
other things) money laundering, bribery and tax fraud, and was found guilty of several criminal offences. The role of the BCCI bank was proactive; the financial institution assisted the disguising of criminal revenues, enabling criminal clients to accumulate economic power, and reinforcing their own power in the process. Passas \& Groskin summarize in the following way the function of institutional support in money laundering: "The more powerful the actors who employ the services of international financial institutions, the greater is the institutions' ability to court attention, purchase influence and outspend control agencies" [19].

\section{Different risks?}

In this section, we aim to clarify the different attitudes towards distinct types of crime. Perhaps attitudes vary depending of the extent of the perceived 'risk' attached to specific crimes. Moreover, different attitudes and approaches may also depend on the amount of risk that criminals themselves (be they burglars or money launderers) encounter in their activity. Do criminals calculate these risks differently? Which choices are made? And can we actually speak of 'choices' in this respect?

\section{Prevention of crime}

The battle against money laundering has grown into a massive, international operation. Since the early $90 \mathrm{~s}$, diverse companies, organisations, judicial and police agencies have been united in an anti money laundering crusade, which takes place on several levels. Such a crusade is only possible when all involved parties work together to prevent money laundering. The cooperation of private entities, such as banks, is crucial in this respect, but the international dimension, inherent to money laundering, also implies a worldwide approach to this phenomenon. Today, the battle against money laundering can be described as an intrusive and megalomaniac project, encompassing public and private services all over the world. We may ask ourselves the following question: to what extent is the size of this anti money laundering machine linked to the motives behind money laundering itself? Does the power motive play a role?

The battle against money laundering is to a large extent based on the work of a system of informants and whistle-blowers who are obliged to inform the authorities when they suspect their clients of attempting unorthodox financial operations. This kind of worldwide and rather intrusive approach is hard to imagine in relation to other crimes. Applied to burglary, this approach would mean the introduction of a system in which insurance companies are obliged to make risk assessments of clients' assets, which would imply that stolen goods, if found in the assets of clients, would have to be seized. Similarly, it would mean the introduction of a whistleblowing system for dealers in second-hand goods which obliged them to identify, register and know all customers and suppliers, and keep track of all transactions. This system would be combined with a thorough enforcement policy. On the other hand, enforcement in this area appears to be needed, as the most popular targets for burglars, apart from money, are gold and jewellery. This implies that there is a market for these goods. This market revolves around pawnbrokers and jewellers, 
although the latter are formally obliged to identify sellers of gold [28]. And why stop at the dealers? Why not impose obligations on all parties involved? In brief, it would seem that the severity of social reaction to crime depends on the interests at stake and on the type of actors victimised.

Of course, the impact of money laundering principally falls upon the state apparatus. The state being the main victim, it is then easy to claim that the 'general interest' is at stake simultaneously. In contrast, burglary will have a marginal impact on the state's interests, as victimisation takes place on an individual level and endangers mostly 'personal interests'.

Apart from the different intensity of social reaction, there are also some similarities between the approach to money laundering and that to burglary: the battle against money laundering is a costly but also entrepreneurial tactic, in which both public and private partners protect their own interests. This 'threat assessment industry' [25] thrives on an image of organised crime that menaces the political and economic interests worldwide. The fear of money laundering becomes an instrument and a convenient support for the involved parties, who all benefit, in one way or another, from the battle against money laundering. The same can be said about the insurance philosophy with regard to burglary. The fear of burglary is also used as a means for selling more and more insurance policies for the benefit not only of the insurance companies, but also of other organisations working on theft prevention (security consultants, private surveillance, CCTV systems, etc.). Both industries take advantage from the spreading of images of fear and distress and from supposed risks run by customers. Although founded on diverse calculations of risks, these industries capitalise on the creation of images as well as on the demand for protection.

\section{Cost-benefit analysis}

When devising anti money laundering strategies, policy makers assume that money launderers are rational individuals making well-pondered choices on the basis of a cost-benefit assessment. Such an assumption implies that a 'follow the money' strategy would scare perpetrators off, as the costs would be higher than the benefits. Broadening the possibilities for confiscating and seizing proceeds of crime is meant to deter potential money launderers and hit them where it hurts most: in their wallets [18]. The philosophy, if any, behind this system is based on the proverbial adage 'crime should not pay'.

If we assume that a cost-benefit approach underpins the '(power) choice' to commit crime, this strategy makes sense. However, its effectiveness has been questioned many times in that criminals are not economists, and criminal motivation is not determined by calculations of costs and benefits [17]. The system is based on the assumption that perpetrators by nature strive for wealth. However, as we suggested earlier, an experienced criminal group will take the confiscation risk for granted, as 'the cost of doing business' [18]. There are other risks involved in the attempt to launder money than just the risk of confiscation or seizure. The preventive system surrounding money laundering may unmask fraudsters or money launderers at the moment when they are preparing to enter the legal market or to improve their position on the legal market. When caught, the criminal background of the funds will be revealed (as happened in the BCCI case), which can cause severe reputational 
damage. For legal entities involved in the money laundering scheme, this may even lead to larger damages, as there is not only a reputational risk involved, but also a regulatory risk: the regulator may impose significant fines or even withdraw the business licence. In order to avoid these risks, money launderers may choose to make use of front men or front companies, who will function as a shield for reputational damage and exposure. Front companies are also useful in making transactions even more obscure, and are mostly used for serious or organised fraud or the abuse of company assets [1].

In respect of burglary, this cost-benefit approach is even more inappropriate: the choice burglars will make is not per se rational: on the contrary, burglars' actions are rather unpredictable [28]. The current approach to prevent burglary is mainly a situational preventive method in which target hardening, security systems and technical appliances are predominant, and ignores the non-rational components of human behaviour [28]. The rational (power) choice assumption is therefore, neither for burglary nor for money laundering, a perfect preventive method. Moreover, the motives of both need to be studied thoroughly if we are to develop strategies that fit the crimes.

\section{To conclude}

Is it only since money laundering has become an international phenomenon that the strategies to tackle it have grown into a global control system? Does money laundering threaten our economy, our politics and our lives more than burglary? Assuming that money laundering may lead to the criminal infiltration of the political and economic spheres, and that this may result in criminals gaining legitimate power, we may argue that the battle against this type of crime needs to be thorough and wide ranging. However, there is a lack of evidence that this is precisely the objective of money launderers. The threat seems, therefore, to be exaggerated.

One of the explanations for the growth of such a global control system may reside in the power motive behind money laundering. When criminal activity results in increasing power accumulation, it may be perceived as particularly threatening, hence the urgent need to prevent it and control its effects.

When we look at aspects of victimisation of burglary and money laundering, particularly at the interests that they respectively threaten, we see a different picture. We might underline that the amounts of money transferred and handled is much higher in money laundering than it is in burglary. However, we lack the statistics to prove this. When we try to assess which people or institutions are actually victimised, another remark could be made. Policymakers convince us of the fact that money laundering harms society as a whole, by threatening the economy and the 'healthy' political and economic climate in a country [13]. What is often forgotten, however, is that money laundering is also functional; it forms a bridge between the legal and the illegal market, not only for drugs dealers, as is assumed, but for all sorts of entrepreneurs in criminal activities [9]. This results in a market in which several illegal, informal and formal entrepreneurs function in their own way and with their own economic objectives. This market is not only highly diverse, but also 
difficult to tackle, specifically when policy remains focused on the traditional view of the money launderer.

The intertwining of several markets is also present within the market of burglary and the subsequent trade in stolen goods. Although burglars themselves mainly function within the illegal economy, the suppliers and the buyer of stolen goods may function within formal economic spheres. However, the aim of these transactions are limited to making a living, to survive, not to gain economic power in a more broad sense. The power motive differentiates money laundering from burglary also in the sense that the power gained through entering the official economy provides money launderers with a competitive advantage on other official operators. Although the focus of policy makers and legislators remains mainly oriented towards organised criminals infiltrating the legal world, we may need to fear the 'business criminal' more.

We have attempted to make clear that different motives related to either money laundering or burglary result in different societal reactions, but also require a different approach toward the criminal groups involved. The drive for power is crucial within money laundering. Laundering is not performed to survive, which on the contrary inspires burglars; money launderers aim at enhancing and consolidating their position in the legal economy. They do not necessarily want to become rich (or richer) but to develop and build their power position.

We cannot illustrate this never-ending pursuit of power more cogently than by referring to the title of a newspaper article published in May 2008: "Most wealthy Belgian is suspected of money laundering" [6].

\section{References}

1. CTIF-CFI (2008). Annual Report 2007. Brussel.

2. De Standaard (24 December 1999). DRIE. Jo Lernout \& Pol Hauspie.

3. De Standaard (22 July 2006). Verdachten Lernout \& Hauspie riskeren vijf jaar cel.

4. De Standaard (23 May 2007) 200 nieuwe burgerlijke partijen op tweede procesdag L\&H.

5. De Standaard (18 October 2007) Dexia en KPMG stellen zich burgerlijke partij in L\&H proces.

6. De Standaard (7 May 2008). Rijkste Belg wordt verdacht van witwassen.

7. Dowding, K. (1996). Power (Concepts in Social Thought). University of Minnesota Press.

8. Heiskala, R. (2001). "Theorizing power: Weber, Parsons, Foucault and neostructuralism". Social Science Information, 40(2), 241-264.

9. Hoogenboom, B. (2006). "Voorbij goed en kwaad van witwassen". Justitiële Verkenningen, 32(2), 76-86.

10. International Monetary Fund (2004). The IMF and the Fight against Money Laundering and the Financing of Terrorism. A Fact Sheet.

11. Kennedy, A. (2005). "Dead Fish across the Trail: Illustrations of Money Laundering Methods". Journal of Money Laundering Control, 8(4), 305-319.

12. Kleemans, E., Brienen, M., et al. (2002). Georganiseerde criminaliteit in Nederland, Tweede rapportage op basis van de WODC-monitor. Den Haag: WODC.

13. Kochan, N. (2006). The Washing Machine. Money, Crime and Terror in the Offshore System. London: Duckworth.

14. Levi, M. (1996). Money Laundering: Risks and Countermeasures. In A. Graycar, \& P. Grabosky (Eds.), Money Laundering in the 21st century: risks and countermeasures. Canberra: Australian Institute of Criminology.

15. Levi, M. \& Reuter P. (2006). Money Laundering Chicago. 
16. Masciandaro, D. (1999). "Money Laundering: the Economics of Regulation". European Journal of Law and Economics, 3, 225-240.

17. Naylor, R. (2007). Criminal profits, terror dollars and nonsense. Tax Justice NL, Seminar on Money Laundering, Tax Evasion and Financial Regulation. Transnational Institute Amsterdam.

18. Nelen, H. (2004). "Hit them where it hurts most? The proceeds-of-crime approach in the Netherlands". Crime, Law and Social Change, 41(5), 517-534.

19. Passas, N., \& Groskin, R. B. (2001). "Overseeing and overlooking: The US federal authorities' response to money laundering and other misconduct at BCCI". Crime, Law and Social Change, 35(1), 141-176.

20. Ruggiero, V. (2007). 'It's the Economy, Stupid! Classifying Power Crime'. International Journal of the Sociology of Law, 35, 163-177.

21. Stessens, G. (2000). Money Laundering: A New International Law Enforcement Model. Cambridge: Cambridge University Press.

22. Suendorf, U. (2001). Geldwäsche: eine kriminologische Untersuchung. Neuwied: Luchterhand.

23. U.S. Department of State (1998). 1997 International Narcotics Control Strategy Report. Washington, DC, Released by the Bureau for International Narcotics and Law Enforcement Affairs.

24. Unger, B. (2006). The amounts and effects of money laundering. Report for the Ministry of Finance. Den Haag.

25. van Duyne, P. (1997). Money Laundering. Pavlov's dog and beyond. European Regional Fraud Conference. Amsterdam

26. van Duyne, P., \& de Miranda, H. (1999). "The emperor's clothes of disclosure: Hot money and suspect disclosures". Crime, Law and Social Change, 31(3), 245-271.

27. Vande Walle, G. (2002). La salle de jeu des criminels en col blanc raffinés. Criminalité financière et économique en Belgique. In P. Ponsaers, \& V. Ruggiero (Eds.), La Criminalité Economique et Financière en Europe (pp. 77-98). Paris: L'Harmattan.

28. Verwee, I., Ponsaers, P., et al. (2007). Inbreken is mijn vak. Textuur en praktijk van woninginbraak. Den Haag: Boom Juridische uitgevers.

29. Williams, P. (1994). 'Transnational Criminal Organisations and International Security'. Survival, 36 (1), 96-113.

30. Wright Mills, Ch. (1956). The Power Elite. New York: Oxford University Press. 